\title{
Penerapan Metode Simpang Tegar untuk Meningkatkan Kemampuan Guru dalam Penulisan PTK dan Artikel Ilmiah
}

\author{
I Wayan Widana ${ }^{1}$ I Made Suarta ${ }^{2}$, I Wayan Citrawan ${ }^{3}$ \\ IKIP PGRI Bali ${ }^{1,2,3}$ \\ iwayanwidana@ikippgribali.ac.id ${ }^{1}$, suarta@ikippgribali.ac.id ${ }^{2}$, citrawan@ikippgribali.ac.id ${ }^{3}$
}

\begin{abstract}
The ability of SMAN 1 Selemadeg and SMAN 1 Kerambitan, Tabanan Regency, Bali Province teachers, in writing Classroom Action Research (CAR) reports and articles is very low. This problem has an impact on the delay of the promotion of teachers for many years, because one of the requirements is not fulfilled in the element of scientific papers. Community service aims to improve the ability of teachers in writing CAR and articles. To achieve these objectives, the Simpang Tegar method is implemented. Data on teacher understanding of the basic concepts of CAR and articles were collected using the test method. While the data on the skills of teachers writing CAR and articles are collected using observation and check-list of tasks given during mentoring. The results obtained are as follows: (1) teacher's understanding of the basic concepts of CAR and scientific articles increased from an average of 57.34 during the pre-test to 73.93 during the post-test; (2) teacher's skills of writing CAR reports and articles increased from an average of 45.41 before mentoring, to 68.58 after mentoring.
\end{abstract}

Keywords: Simpang Tegar; CAR; articles; SMAN 1 Selemadeg; SMAN 1 Kerambitan.

\begin{abstract}
Abstrak
Kemampuan guru-guru SMAN 1 Selemadeg dan SMAN 1 Kerambitan, Kabupaten Tabanan, Provinsi Bali, dalam menulis laporan Penelitian Tindakan Kelas (PTK) dan artikel ilmiah sangat rendah. Permasalahan ini berdampak pada tertundanya kenaikan pangkat guru-guru bertahuntahun, karena salah satu persyaratan tidak dipenuhi pada unsur karya ilmiah. Pelatihan dan pendampingan ini bertujuan untuk meningkatkan kemampuan guru dalam penulisan PTK dan artikel ilmiah. Guna mencapai tujuan pelatihan dan pendampingan penulisan laporan PTK dan artikel ilmiah tersebut maka diimplementasikan metode Simpang Tegar. Data pemahaman guru terhadap konsep dasar PTK dan artikel ilmiah dikumpulkan dengan metode tes. Sedangkan data keterampilan guru menulis PTK dan artikel ilmiah dilakukan dengan observasi dan check-list terhadap tugas-tugas yang diberikan selama pendampingan. Hasil yang diperoleh sebagai berikut: (1) pemahaman guru terhadap konsep dasar PTK dan artikel ilmiah meningkat dari rerata 57,34 pada saat pre-test menjadi 73,93 saat post-test; (2) keterampilan guru penulisan PTK dan artikel ilmiah meningkat dari rerata 45,41 sebelum pendampingan, menjadi 68,58 setelah pendampingan.
\end{abstract}

Kata kunci: Simpang Tegar; PTK; Artikel ilmiah; SMAN 1 Selemadeg; SMAN 1 Kerambitan. 


\section{A. Pendahuluan}

SMA Negeri 1 Selemadeg dan SMA Negeri 1 Kerambitan berlokasi di Kabupaten Tabanan, Provinsi Bali. Kedua sekolah tersebut memiliki karakteristik yang hampir sama, ditinjau dari SDM guru dan hasil belajar yang dicapai siswa. Tahun pelajaran 2016/2017 SMA Negeri 1 Selemadeg didukung oleh 80 orang guru dan 26 orang tenaga administrasi, serta mengelola siswa sebanyak 576 orang. Sedangkan SMA Negeri 1 Kerambitan memiliki 99 orang guru dan 29 orang tenaga administrasi, serta mengelola siswa sebanyak 398 orang.

Keterampilan menulis bagi seorang guru merupakan kompetensi yang sangat penting. Kemampuan menulis berkaitan erat dengan kemampuan untuk mengomunikasikan gagasan-gagasan keilmuan baik teoretik maupun praktis. Menulis publikasi ilmiah bertujuan untuk memperkaya khasanah ilmu, atau mendapatkan respon dari khalayak profesional untuk terlibat dalam suatu fenomena keilmuan yang dihadapi. Dalam konteks kebahasaan, menulis sebuah karya ilmiah membutuhkan keterampilan tersendiri, melalui penguasaan kaidah-kaidah yang dipersyaratkan dalam menulis. Keterampilan menulis bukanlah suatu keterampilan kodrati, tetapi suatu keterampilan yang dapat dilatih dan dipelajari. Hal ini berarti, bahwa keterampilan seseorang untuk mengungkapkan pikirannya melalui tulisan dapat diasah dan ditingkatkan melalui latihan-latihan. Semakin sering seseorang melakukan latihan menulis, maka keterampilan menulis semakin baik (Dwiyogo, 2012).

Salah satu unsur utama yang dinilai dalam kenaikan pangkat/jabatan guru setingkat lebih tinggi adalah pengembangan keprofesian berkelanjutan yaitu pengembangan kompetensi guru yang dilaksanakan sesuai dengan kebutuhan, bertahap, berkelanjutan untuk meningkatkan profesionalitasnya. Bentuk kegiatan pengembangan berkelanjutan antara lain publikasi ilmiah (Kemdikbud, 2009). Jenis publikasi ilmiah/karya inovatif untuk setiap jenjang jabatan yang harus dipenuhi oleh guru yang akan mengajukan kenaikan pangkat/jabatan guru adalah presentasi pada forum ilmiah, publikasi hasil penelitian atau gagasan inovatif pada bidang pendidikan formal, dan publikasi buku teks pelajaran, buku pengayaan dan/atau pedoman guru (Kemdikbud, 2016).

Permasalahan yang dihadapi oleh guru-guru di sekolah mitra adalah keterampilan menulis karya ilmiah guru pada kedua sekolah mitra sangat rendah. Hal ini dapat dilihat dari minimnya publikasi ilmiah yang dilakukan guru berupa karya tulis baik berupa buku, laporan penelitian, atau artikel ilmiah yang dipublikasikan dalan jurnal. Keterbatasan guru-guru untuk melaksanakan publikasi ilmiah berdampak pada tertundanya kenaikan pangkat/jabatan guru bertahun-tahun. Akibatnya kebanyakan guruguru bertahan pada pangkat/golongan Pembina, IV/a dan enggan untuk mengurus kenaikan pangkat yang lebih tinggi lagi.

Sesuai dengan data yang diperoleh dari bagian kepegawaian di masing-masing sekolah mitra dinyatakan bahwa untuk di SMA Negeri 1 Kerambitan, dari 99 orang guru yang sudah berhasil mencapai pangkat/golongan Pembina Tk. I/IVb hanya 19 orang atau sekitar $20,20 \%$ sedangkan sisanya sekitar 79,80\% masih pada pangkat Pembina, IV/a ke bawah. Sedangkan di SMA Negeri 1 Selemadeg jumlah guru yang sudah mencapai pangkat/golongan Pembina Tk. 
I/IVb hanya 8 orang dari 80 orang guru atau sekitar 10\%, sedangkan $90 \%$ dari jumlah guru masih pada pangkat Pembina, IV/a ke bawah.

Hasil wawancara dengan beberapa orang guru pada kedua sekolah mitra, menyatakan bahwa guru merasa enggan melaksanakan Penelitian Tindakan Kelas (PTK) karena trauma ditolak beberapa kali oleh Tim Penilai Angka Kredit Jabatan Guru, sehingga kenaikan pangkatnya tertunda dalam waktu yang cukup lama. Para guru mengaku tidak mengetahui secara pasti bagaimana seharusnya menyusun laporan PTK yang dapat diterima oleh Tim Penilai. Kekecewaan guru ini dapat dipahami, karena merasa gagal berkali-kali untuk menulis laporan PTK akibatnya motivasi untuk melaksanakan PTK menjadi rendah. Berdasarkan pengakuan tersebut diduga bahwa para guru belum memiliki pengetahuan dan pemahaman yang cukup untuk melaksanakan PTK. Para guru harus diberikan pengetahuan tentang pelaksananaan PTK mulai dari penyusunan proposal, pelaksanaan, dan penulisan laporan PTK.

Kesulitan lain yang dirasakan oleh guru adalah menulis artikel ilmiah yang dapat dimuat dalam jurnal nasional sehingga dapat diperhitungkan angka kreditnya. Beberapa orang guru mengaku sudah pernah menulis artikel dan mengajukan artikel ke redaksi jurnal tertentu, namun beberapa kali ditolak karena tidak memenuhi persyaratan untuk dimuat dan dipublikasikan. Persamalahan ini membuat para guru di kedua sekolah mitra pasrah, sehingga merasa enggan untuk mengurus kenaikan pangkat mereka.

Untuk mengatasi permasalahanpermasalahan di atas diimplementasikan metode Sosialisasi dan Pendampingan Terintegrasi (Simpang Tegar). Pada tahap pertama guru-guru di sekolah mitra diberikan sosialisasi selama satu hari (10 jam, @45 menit). Tujuan sosialisasi adalah meningkatkan pemahaman guru tentang konsep dasar PTK dan artikel ilmiah. Selanjutnya, kegiatan tahap kedua dilaksanakan pendampingan terintegrasi. Pada tahap pendampingan dilakukan penguatan-penguatan terhadap pemahaman guru tentang konsep dasar PTK, diskusi alternatif topik yang dapat diangkat dalam PTK, dan artikel ilmiah dengan contohcontoh. Guru juga diberikan tugas menyusun proposal PTK dan sebuah artikel yang akan dipublikasikan. Kegiatan pendampingan dilakukan dalam beberapa kali pertemuan. Selama kegiatan pendampingan dilakukan kegiatan observasi untuk melihat perkembangan keterampilan guru menulis proposal PTK dan artikel ilmiah.

Kegiatan sosialisasi dilaksanakan pada kedua sekolah mitra. Pada gambar 1 di bawah ini menunjukkan kegiatan sosialisasi di salah satu sekolah mitra yaitu di SMA Negeri 1 Kerambitan. Materi tentang konsep dasar PTK disajikan oleh Dr. I Wayan Widana, S.Pd., M.Pd. Kegiatan sosialisasi berlangsung dalam suasana kekeluargaan sehingga peserta secara bebas dapat mengajukan pertanyaan-pertanyaan saat sesi sosialisasi berlangsung.

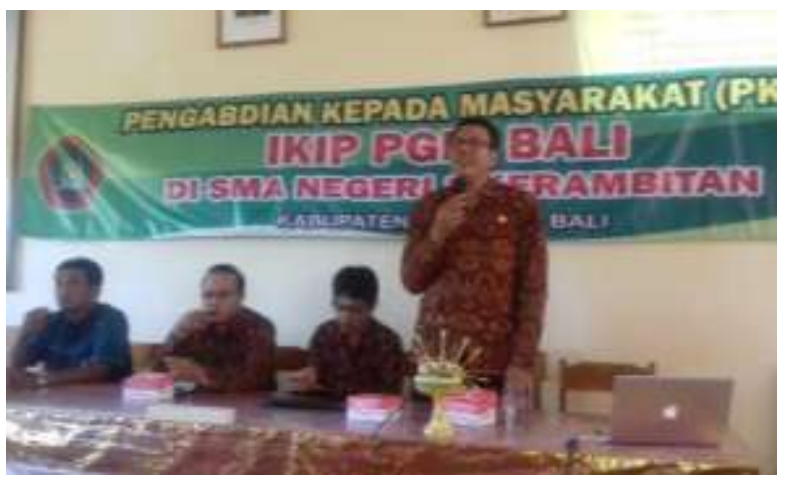

Gambar 1. Kegiatan Sosialisasi 
Pada tahap awal, perserta lebih banyak diam sehingga narasumber berinisiatif memberikan beberapa pertanyaan yang sifatnya memberikan stimulus untuk memotivasi peserta mengajukan pertanyaan dan memberikan argumen. Melalui pertanyaan stimulus tersebut, muncul komentar-komentar dan pertanyaanpertanyaan menjadi berkembang. Ternyata banyak masih pemahaman peserta yang remang-remang. Rupanya hal tersebut membuat mereka diam pada sesi awal. Setelah peserta terbuka terhadap masalahmasalah yang dihadapi selama ini, diskusi akhirnya berlangsung hangat dan interaktif. Kegiatan sosialisasi berlangsung dalam 4 sesi. Masing-masing narasumber secara bergiliran menyajikan materi pada sesi sesuai jadwal yang telah ditetapkan. Pada akhir kegiatan sosialisasi semua peserta mendapatkan materi yang disajikan, sehingga dapat dijadikan bahan pembelajaran di rumah masing-masing.

\section{B. PELAKSANAAN DAN METODE}

Kegiatan PKM dilaksanakan pada 2 sekolah mitra yaitu di SMAN 1 Selemadeg dan SMAN 1 Kerambitan. Kedua sekolah mitra tersebut berlokasi di Kabupaten Tabanan, Provinsi Bali. Pelaksanaan PKM dilakukan secara terpisah pada masingmasing sekolah. Kegiatan dilaksanakan pada bulan Juni-September 2018. Kegiatan PKM diikuti oleh 124 orang guru yang berasal dari 2 sekolah mitra, terdiri atas 62 orang guru SMAN 1 Kerambitan dan 62 orang dari SMAN 1 Selemadeg. Seluruh peserta berlatar belakang pendidikan guru dan mengajar mata pelajaran sesuai dengan ijazah pendidikan terakhir yang dimiliki serta tergabung ke dalam kelompok-kelompok MGMP.

Metode Simpang Tegar merupakan metode pelatihan yang mengkombinasikan kegiatan sosialisasi dan pendampingan secara terintegrasi. Kegiatan PKM diawali dengan sosialisasi. Materi sosialisasi disusun dan dikembangkan oleh Tim PKM IKIP PGRI Bali mengacu pada konsep dasar PTK dan penulisan artikel ilmiah yang diadaptasi dari berbagai literatur berupa buku, artikel, dan peraturan perundang-undangan. Materi PKM disajikan secara bergiliran oleh Tim PKM IKIP PGRI Bali. Pada kegiatan sosialisasi, para guru diberikan kesempatan untuk tanya jawab seputar konsep dasar PTK dan penulisan

artikel ilmiah. Adapun materi pokok kegiatan sosialisasi disajikan pada Tabel 1 .

Tabel 1. Materi Pokok Sosialisasi PKM

\begin{tabular}{clc}
\hline No. & \multicolumn{1}{c}{ M a t e r i } & $\begin{array}{c}\text { Waktu (@ } \\
\text { 45 menit) }\end{array}$ \\
\hline 1. & Pembukaan & 1 \\
\hline 2. & Konsep Dasar PTK & 2 \\
\hline 3. & Prosedur pelaksanaan PTK & 2 \\
\hline 4. & $\begin{array}{l}\text { Pengembangan Keprofesian } \\
\text { Berkelanjutn (Publikasi } \\
\text { Ilmiah) }\end{array}$ & 2 \\
\hline 5. & $\begin{array}{l}\text { Teknik Penulisan Artikel } \\
\text { Ilmiah }\end{array}$ & 2 \\
\hline 6. & Penutupan & 1 \\
\hline \multicolumn{1}{c}{ Jumlah } & $\mathbf{1 0}$ \\
\hline
\end{tabular}

Konsep Dasar PTK

PTK merupakan suatu penelitian reflektif dan suatu model penelitian pengalaman, di mana semua individu dilibatkan dalam studi sebagai peserta. Penelitian tindakan mempunyai tujuan utama menyediakan suatu kerangka penyelidikan kualitatif oleh para guru dan peneliti dalam rangka meningkatkan proses dan hasil belajar (Hong \& Lawrence, 2011); (Mills, 2000).

Pengertian lainnya, PTK adalah suatu kegiatan penelitian yang dilakukan dengan menganalisis sebuah kegiatan belajar yang diberikan tindakan, yang bertujuan untuk 
memecahkan masalah atau meningkatkan mutu pembelajaran di kelas tersebut (Sukardiyono, 2015). Pada dasarnya ciri utama dari penelitian tindakan adalah adanya intervensi atau perlakuan tertentu untuk perbaikan kinerja dalam kehidupan seharihari (Kunlasomboon, Wongwanich, \& Suwanmonkha, 2015).

\section{Tujuan PTK}

Secara umum, tujuan melaksanakan

PTK adalah sebagai berikut (Kunandar, 2008).

1) Memecahkan permasalahan nyata yang terjadi di dalam kelas yang berkaitan dengan interaksi antara guru dan siswa yang sedang belajar.

2) Meningkatkan profesionalisme guru dan menumbuhkan budaya akademik di kalangan guru.

3) Peningkatan kualitas praktik pembelajaran di kelas secara terusmenerus mengingat masyarakat berkembang secara cepat.

4) Sebagai alat training in service, yang memperkuat kapasitas guru dalam bentuk keterampilan dan metode pembelajaran, mempertajam kekuatan analitisnya dan mempertinggi kepekaan profesi.

5) Sebagai jembatan untuk meningkatkan inovasi dalam pembelajaran.

6) Meningkatkan mutu hasil belajar melalui perbaikan praktik pembelajaran di kelas, mengembangkan berbagai jenis keterampilan, dan meningkatkan motivasi belajar siswa.

7) Meningkatkan efisiensi manajemen pendidikan, peningkatan dan perbaikan proses dan hasil pembelajaran.

\section{Prosedur Pelaksanaan PTK}

PTK pada umumnya dilaksanakan dalam beberapa siklus. Setiap siklus diakhiri dengan kegiatan refleksi terhadap pelaksanaan siklus. Hasil pelaksanaan siklus dibandingkan dengan kriteria keberhasilan yang ingin dicapai. Apabila hasil pelaksanaan siklus belum mencapai kriteria, maka dilanjutkan dengan siklus berikutnya. Demikian seterusnya, pelaksanaan siklus akan berakhir apabila kriteria yang telah ditetapkan sudah tercapai. Prosedur pelaksanaan PTK pada setiap siklus terdiridari empat langkah utama, yaitu perencanaan (planning), tindakan (action), pengamatan (observation), dan refleksi (reflection). Langkah kegiatan tersebut dapat dijabarkan sebagai berikut (Kemis \& Mc. Taggart, 1992).

1. Perencanaan Tindakan (planning) meliputi rencana langkah-langkah yang akan ditempuh dalam mengatasi masalah. Perencanaan meliputi setting penelitian, meliputi kegiatan menyusun skenario tindakan, aspek tindakan, kapan tindakan harus dilakukan, dan dengan siapa tindakan akan dilakukan, serta tolok ukur keberhasilan tindakan.

2. Melaksanakan tindakan (action), merupakan perlakuan yang dikenakan pada subjek penelitian agar tujuan penelitian tercapai sesuai dengan skenario tindakan.

3. Melakukan pengamatan (observation). Pengamatan dilakukan untuk dua hal yaitu: (a) pengamatan terhadap jalannya penelitian dalam upaya validasi penelitian tindakan, apakah pelaksanaan penelitian telah dilaksanakan sesuai dengan rancangan penelitian, apakah semua aspek tindakan telah dilakukan sesuai dengan skenario tindakan; (b) pengamatan terhadap perilaku siswa agar dampak tindakan yang diinginkan dapat tercapai sesuai dengan tujuan penelitian.

4. Menganalisis dan merefleksi hasil penelitian. Setiap akhir pertemuan kelas dilakukan analisis terhadap hasil pengamatan apakah hasil sesuai tolok ukur keberhasilan tindakan dalam 
skenario tindakan. Jika belum sesuai, dilakukan analisis sebab-sebabnya, kemudian dilakukan sebagai upaya perbaikan atau penyempurnaan untuk pertemuan berikutnya. Siklus akan dihentikan apabila tolok ukur yang ditetapkan sudah tercapai.

Untuk menambah wawasan guru dalam pemilihan topik PTK, disajikan informasi tentang kebijakan pemerintah memasuki revolusi industri 4.0 di bidang penilaian yaitu pengembangan asesmen Higher Order Thinking Sklills (HOTS). Asesmen HOTS merupakan asesmen untuk mengukur kemampuan berpikir tingkat tinggi yaitu menganalisis, mengevaluasi, dan mengkreasi (Widana, 2017a). Dalam praktiknya, asesmen HOTS tidak dapat dipisahkan dengan pembelajaran HOTS. Sehingga para guru disarankan menggunakan pembelajaran HOTS, sebelum menguji siswa menggunakan asesmen HOTS (Widana, 2017b). Asesmen HOTS telah berhasil meningkatkan kemampuan berpikir krtitis siswa sehingga direkomendasikan sebagai asesmen untuk membekali siswa kemampuan berpikir tingkat tinggi (Widana, 2018).

\section{Artikel Ilmiah}

Salah satu sub unsur dari Pengembangan Keprofesian Berkelanjutan (PKB) adalah publikasi ilmiah yaitu membuat karya tulis ilmiah dan mempublikasikannya yang dapat berupa hasil penelitian, tinjauan ilmiah, buku, modul, artikel ilmiah, dan sejenisnya (Kemdikbud, 2016). Organisasi di dalam artikel ilmiah secara umum terdiri dari judul, nama dan alamat penulis, abstrak, pendahuluan, bahan, metode, hasil, diskusi, kesimpulan, ucapan terima kasih dan pustaka (Hidayat, 2006); (Wardhani, 2007).

Artikel Ilmiah yang ditulis dalam jurnal, dapat dikelompokkan menjadi 2 jenis, yaitu: (1) artikel konseptual dan (2) artikel hasil penelitian (Dwiyogo, 2012). Artikel konseptual adalah hasil pemikiran penulis berkaitan dengan suatu deskripsi tentang suatu masalah yang dituangkan dalam bentuk tulisan. Bagian penting dari artikel konseptual adalah pendapat atau pendirian penulis tentang pokok persoalan yang dibahas. Jadi artikel konseptual bukan hanya berupa kumpulan pendapat, melainkan kajian yang mendalam tentang suatu pokok persoalan. Artikel konseptual terdiri atas unsur-unsur pokok, yaitu: judul, nama penulis, abstrak, kata kunci, pendahuluan, bagian inti atau pembahasan (dengan sub judul), penutup, dan daftar pustaka. Sedangkan artikel hasil penelitian adalah sebuah artikel yang dihasilkan dari suatu laporan penelitian. Sebelum disajikan sebagai artikel dalam jurnal, laporan penelitian tersebut terlebih dahulu disusun kembali agar memenuhi sebagai sebuah artikel jurnal. Artikel hasil penelitian bukan sebagai ringkasan saja, melainkan suatu laporan baru dalam bentuk yang lebih singkat, akan tetapi merangkum keseluruhan dari laporan penelitian. Artikel dalam jurnal hasil penelitian terdiri atas unsur-unsur pokok, yaitu: judul, nama penulis, abstrak, kata kunci, pendahuluan, metode, hasil penelitian, pembahasan, pembahasan, kesimpulan, saran, daftar rujukan. Secara rinci aturan penulisan suatu jurnal tertentu diatur dalam sebuah aturan yang sering disebut gaya selingkung.

\section{Gaya Selingkung Jurnal}

Gaya selingkung jurnal merupakan pedoman tata cara penulisan sebuah jurnal. Masing-masing jurnal memiliki gaya selingkung yang berbeda-beda. Pada dasarnya terdapat 3 komponen utama gaya selingkung suatu jurnal, yaitu (1) perwajahan dan format, (2) pola penulisan, serta (3) 
kedalaman dan kerincian penyajian. Tampilan wajah utama jurnal yang terkait dengan ukuran, warna, hiasan, isi, dan tata letak sampul setiap terbit merupakan kesan pertama yang diamati orang. Format dan tata letak halaman, tipe dan ukuran huruf, sistem penomoran, organisasi atau pengaturan isi naskah, jenis kertas, dan faktor penampilan fisik merupakan tolok ukur kecermatan para penyunting mempertahankan keunggulan gaya selingkungnya (Kushartanti, 2014). Dengan demikian, maka dalam penulisan artikel ilmiah sangat penting memperhatikan gaya selingkung jurnal yang akan dituju. Pada setiap jurnal, gaya selingkung umumnya dibuat dalam bentuk template. Dalam template tersebut diterakan aturan main atau tata cara penulisan artikel ilmiah yang dapat dimuat pada jurnal tertentu.

Kegiatan selanjutnya adalah melaksanakan kegiatan pendampingan terintegrasi. Pendampinagn terintegrasi merupakan pendampingan yang mengintegrasikan kegiatan bimbingan (mentoring), penugasan, presentasi hasil kerja, interaksi antar peserta satu dengan yang lainnya dalam satu MGMP, diskusi, sampai menghasilkan sebuah karya ilmiah, Agar kegiatan pendampingan tidak mengganggu jam mengajar guru, maka pelaksanaan kegiatan disesuaikan dengan jadwal pertemuan rutin MGMP. Selama kegiatan praktik, guru-guru didampingi oleh narasumber (Tim Pelaksana PKM). Selama pelaksanaan kegiatan pendampingan terintegrasi, dilakukan kegiatan observasi terhadap keterampilan guru menulis karya tulis ilmiah (PTK dan artikel ilmiah). Kemajuan-kemajuan yang dicapai oleh guru dicatat dalam bentuk check-list.

Untuk mengetahui pemahaman guruguru di sekolah mitra terhadap konsep dasar PTK dan penulisan artikel ilmiah, sebelum kegitan sosialisasi dimulai guru-guru diberikan pre-test dan setelah diberikan sosialisasi diberikan post-test. Soal pre-test dan post-test dikembangkan oleh Tim PKM IKIP PGRI Bali, masing-masing terdiri atas 30 butir soal bentuk pilihan ganda dengan 5 option. Kisi-kisi soal mengacu pada konsep dasar PTK dan penulisan artikel ilmiah yang diadaptasi dari berbagai literatur berupa buku, artikel, dan peraturan perundangundangan. Sebelum diujikan soal pre-test dan post-test terlebih dahulu divalidasi oleh pakar meliputi uji materi (substansi), konstruksi, dan kebahasaan. Hanya soal-soal yang dinyatakan lolos uji validasi yang digunakan dalam soal pre-test dan post-test.

\section{C.HASIL DAN PEMBAHASAN}

Setelah diimplementasikan metode Simpang Tegar, dari 124 orang guru yang diberikan treatment berupa sosialisasi, 110 orang guru pemahamannya meningkat atau sekitar $88,71 \%$. Sedangkan dilihat dari aspek keterampilan, dari 124 orang guru ternyata 114 orang guru keterampilannya meningkat atau sekitar 91,94\%. Data selengkapnya disajikan dalam Tabel 2.

Tabel 2. Hasil PKM SMAN 1 Selemadeg dan SMAN 1 Kerambitan

\begin{tabular}{lcccc}
\hline \multirow{2}{*}{ STATISTIK } & \multicolumn{2}{c}{ Pemahaman } & \multicolumn{2}{c}{ Keterampilan } \\
\cline { 2 - 5 } & Pre Tes & Post Tes & Pre & Post \\
\hline Rerata & 57.34 & 73.93 & 45.41 & 68.58 \\
\hline Nilai Maks & 70.00 & 96.67 & 79.17 & 83.33 \\
\hline Nilai Min & 33.33 & 60.00 & 29.17 & 50.00 \\
\hline SD & 7.16 & 8.37 & 7.00 & 9.26 \\
\hline
\end{tabular}

Berdasarkan data pada Tabel 2 di atas terlihat bahwa terjadi peningkatan nilai dari hasil tes awal ke tes akhir pada kedua sekolah mitra. Hal itu berarti bahwa pemahaman guru meningkat tentang penulisan artikel ilmiah 
dan PTK. Pada pre-test rerata pemahaman peserta 57,34 meningkat menjadi 73,93 pada saat post-test.

Peningkatan pemahaman peserta tentang konsep dasar PTK dan artikel ilmiah tersebut disebabkan oleh treatment yang diberikan berupa sosialisasi. Materi-materi yang disajikan dirasakan sangat menarik dan bermanfaat oleh para guru karena sebelumnya guru-guru di sekolah mitra belum pernah mendapatkan informasi terkait dengan konsep dasar PTK dan penulisan artikel ilmiah secara praktis. Selama kegiatan sosialisasi berlangsung pada guru terlihat sangat antusias mengikuti kegiatan tersebut. Diskusi berlangsung hangat, demikian juga terjadi multi interaksi antara narasumber dan peserta serta antara peserta dan peserta lainnya.

Kegiatan pendampingan merupakan tindak lanjut kegiatan sosialisasi. Pada Gambar 2 di bawah ini menunjukkan saat kegiatan pendampingan berlangsung. Terlihat peserta sangat antusias berdiskusi dengan narasumber. Diskusi seperti ini sangat membantu narasumber untuk mengetahui tingkat pemahaman dan keterampilan peserta untuk menulis laporan PTK dan artikel ilmiah. Di lain pihak, bantuan individual yang diberikan oleh narasumber dirasakan sangat efektif oleh peserta untuk meningkatkan pemahaman dan keterampilannya. Peserta yang sudah paham substansi PTK dan artikel ilmiah ternya mampu mengimbaskan pengetahuannya kepada peserta lainnya.

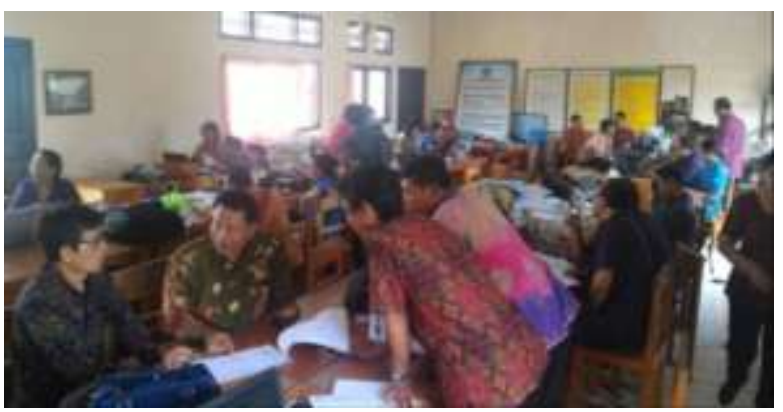

Gambar 2. Pendampingan Terintegrasi

Diskusi sangat menarik juga terjadi pada pemilihan topik PTK, karena selama ini topik PTK yang dibuat oleh guru hampir semua dikaitkan dengan metode pembelajaran saja. Hampir semua guru di sekolah mitra yang pernah mencoba melaksanakan PTK topiknya sama yaitu model pembelajaran atau metode pembelajaran. Padahal faktor-faktor yang mempengaruhi hasil belajar bukan hanya model atau metode pembelajaran saja, tetapi alat peraga, media pembelajaran, instrumen evaluasi hasil belajar, bahkan pemberian reward dan punishment juga bisa mempengaruhi hasil belajar siswa. Dengan diskusi tersebut para guru akhirnya wawasannya lebih terbuka dalam memilih topik yang akan dijadikan fokus dalam melaksanakan PTK.

Pengetahuan baru yang juga dirasakan sangat bermanfaat oleh guru adalah ketika diskusi tentang perbedaan tahap pelaksanaan (action) PTK pada siklus 1 dan siklus 2 . Selama ini pemahaman guru tentang pelaksanaan (action) siklus 1 dan siklus 2 sama. Kesalahan inilah yang sering dilakukan oleh guru sehingga laporan hasil PTK ditolak oleh Tim Penilai angka kredit jabatan guru. Secara umum memang langkah-langkah pembelajarannya sama, tetapi ada perbedaan setelah peneliti menemukan kendala-kendala atau kelemahan pelaksanaan PTK pada siklus 1. Berdasarkan hasil observasi yang dilakukan pada saat 
siklus 1 yang dituangkan dalam catatan harian, dilakukan refleksi dan analisis terhadap kendala-kendala yang dijumpai. Hasil analisis dan refleksi terhadap kelemahan-kelemahan tersebut dilakukan penyempurnaan langkah-langkah pembelajaran pada siklus 2. Sehingga ada perbedaan langkah tahap pelaksanaan (action) PTK pada siklus 1 dan siklus 2.

Demikian juga diskusi berlangsung hangat ketika diskusi tentang penulisan artikel ilmiah. Pemahaman guru selama ini adalah artikel ilmiah yang dapat diajukan pada jurnal tertentu hanya bersumber pada hasil penelitian. Padahal artikel itu ada 2 jenis, yaitu artikel konseptual dan artikel hasil penelitian. Diskusi ini membuka wawasan para guru untuk mulai menulis jurnal konseptual, yang ditulis berdasarkan analisis dan sintesa dari beberapa konsep dan teori pada literatur yang dibaca.

Pengetahuan lain yang juga dirasakan sangat berharga oleh guru adalah tata cara penulisan daftar kepustakaan. Selama ini para guru menulis daftar kepustakaan secara manual, sehingga sangat mungkin ada beberapa sumber yang dikutip tidak masuk ke dalam daftar pustaka. Setelah diperkenalkan cara menulis daftar kepustakaan menggunakan salah satu aplikasi yaitu Mendeley, para guru merasa sangat senang karena dirasakan sangat praktis dan membantu, sehingga tidak perlu menulis daftar pustaka secara manual. Begitu selesai mensitasi literatur tertentu, maka daftar pustaka sudah jadi dan model penulisannya dapat disesuaikan misalnya style penulisan model APA (American Psychological Assosiation), IEEE, atau style lainnya sesuai dengan aturan selingkung jurnal tertentu.

Semangat para guru pada kedua sekolah mitra untuk mengikuti sosialisasi sangat tinggi dan patut diberikan apresiasi. Antusiasme para guru tersebut muncul karena mereka sangat membutuhkan pengetahuan tentang konsep dasar PTK dan penulisan artikel ilmiah. Bahkan beberapa guru menyatakan bahwa mereka harus bisa segera naik pangkat/jabatan setelah menghasilkan karya publikasi ilmiah melalui kegiatan PKM ini.

Sesuai dengan hasil PKM yang disajikan pada tabel 2 di atas, terlihat bahwa keterampilan guru untuk menulis laporan PTK dan artikel ilmiah meningkat. Peningkatan keterampilan tersebut tidak terlepas dari pengetahuan yang dimiliki saat mengikuti kegiatan sosialisasi. Seperti pada kegiatan sosialisasi, antusiasme para guru sangat tinggi. Hal-hal yang dirasakan masih kurang jelas pada kegiatan sosialisasi didiskusikan kembali pada saat pendampingan terintegrasi.

Pada tahap pertama kegiatan pendampingan, para guru dibimbing untuk memilih topik PTK pada kelompok MGMP. Masing-masing anggota MGMP diberi tugas untuk menulis sebuah proposal PTK. Keterampilan guru mulai diobservasi dan dicatat dalam check-list. Setiap anggota MGMP ditugaskan membuat kerangka proposal, dimulai dengan perumusan judul PTK. Terjadi diskusi yang sangat menarik ketika masing-masing anggota MGMP mempresentasikan kerangka proposal yang telah dibuat. Banyak masukan dari teman sejawat terkait dengan perumusan judul yang tepat sesuai dengan topik yang diangkat.

Dari presentasi hasil kerja guru, dicatat beberapa kemajuan yang dicapai seperti keterampilan memilih topik, merumuskan judul PTK, keterampilan memilih literatur yang sesuai, tata cara sitasi, dan menggunakan aplikasi Mendeleye untuk menulis daftar pustaka secara otomatis. Pada tahap awal beberapa guru masih kesulitan memilih topik yang akan diangkat dalam PTK. Hal itu disebabkan oleh kurangnya wawasan guru tentang topik-topik apa saja 
yang dapat diangkat dalam penulisan PTK. Namun melalui bimbingan individual permasalahan tersebut dapat diatasi.

Pada kegiatan praktik menulis proposal PTK, beberapa guru sangat kesulitan untuk menuangkan idenya dalam bentuk tulisan. Setelah duduk berjam-jam tidak satu kalimat pun bisa ditulis. Guru tersebut seolah-olah kehabisan kata-kata, padahal kegiatan menulis belum dimulai. Kondisi tersebut diakibatkan oleh rendahnya kemampuan guru untuk menuangkan idenya dalam bahasa tertulis. Di sinilah peran strategis bimbingan individual untuk mengatasi kesulitan guru yang baru mulai belajar menulis karya tulis ilmiah. Dengan tanya jawab guru tersebut diberikan umpan untuk menuangkan idenya dalam bahasa tertulis.

Fenomena menarik lainnya adalah ketika guru mulai menuliskan landasan teori pada Bab II proposal. Kesulitan yang dialami oleh guru adalah mendapatkan literatur yang sesuai dengan topik yang diangkat, baik berupa buku, jurnal, atau hasil-hasil penelitian yang relevan. Kesulitan tersebut diakibatkan oleh kemampuan guru menggunakan IT masih rendah. Sebagian besar guru belum familiar melakukan kegiatan browsing di internet menggunakan Google. Padahal kesulitan tersebut sebenarnya akan terjawab apabila guru-guru sudah familiar dengan Google. Untuk mengatasi permasalahan itu, maka dalam pendampingan tersebut guru-guru dilatih bagaimana memanfaatkan IT dalam penelusuran literatur melalui internet, sebagai materi tambahan.

Setelah mendapatkan treatment berupa impelementasi metode Simpang Tegar, beberapa guru sudah berhasil menulis artikel ilmiah dan sudah diterbitkan pada Jurnal Widyadari Vol. 20 No. 2 Edisi Oktober 2018 IKIP PGRI Bali, ISSN: 1907-3232. Guruguru juga sudah berhasil menulis proposal
PTK sesuai dengan mata pelajaran yang diampunya. Hal ini merupakan indikator bahwa keterampilan guru untuk menulis artikel ilmiah dan proposal PTK meningkat..

\section{PENUTUP}

\section{Simpulan}

Penerapan metode Simpang Tegar telah berhasil meningkatkan pemahaman dan keterampilan guru SMAN 1 Selemadeg dan SMAN 1 Kerambitan, di Kabupaten Tabanan, Provinsi Bali, dalam melaksanakan PTK dan menulis artikel ilmiah. Keberhasilan itu dicapai karena keunggulan yang dimiliki oleh metode Simpang Tegar berupa. Pendampingan terintegrasi yang dilakukan dengan memadukan bimbingan individual, kerja kelompok, penugasan, pengawasan, presentasi hasil, sampai pada produk tugas akhir yang dirasakan sangat cocok oleh guru di SMAN 1 Selemadeg dan SMAN 1 Kerambitan, di Kabupaten Tabanan, Provinsi Bali.

\section{Saran}

Pola pembinaan guru untuk meningkatkan kemampuan melaksanakan PTK dan menulis artikel ilmiah menggunakan metode Simpang Tegar, dapat diadaptasi di tempat lain. Kendala-kendala teknis yang dijumpai dalam pelaksanaan metode Simpang Tegar antara lain penguasaan guru terhadap teknologi informasi. Oleh karena itu, sebelum mengimplementasikan metode Simpang Tegar sangat dianjurkan untuk memberikan materi tambahan tentang pemanfaatan teknologi informasi sebagai materi prasyarat agar dalam pelaksanaan PKM lebih mudah dan lancar. 


\section{Ucapan Terima Kasih}

Pada kesempatan yang sangat baik ini, ucapan terima kasih dan penghargaan yang setinggi-tingginya disampaikan kepada: 1) Direktorat Riset dan Pengabdian Masyarakat (DRPM), Direktorat Jenderal Penguatan Riset dan Pengembangan, Kementerian Riset, Teknologi, dan Pendidikan atas pendanaan yang diberikan Tahun 2018 dan kepercayaan yang diberikan kepada Tim PKM IKIP PGRI Bali;

2) Rektor IKIP PGRI Bali atas kepercayaan dan dukungannya, sehingga PKM dapat terselenggara dengan baik;

3) Kepala Dinas Pendidikan Provinsi Bali atas izin dan dukungannya dalam pelaksanaan PKM IKIP PGRI Bali;

4) Kepala SMAN 1 Selemadeg dan Kepala SMAN 1 Kerambitan, Kabupaten Tabanan, Provinsi Bali serta seluruh Dewan Guru yang telah berpartisipasi aktif dalam pelaksanaan PKM.

\section{E. DAFTAR PUSTAKA}

Dwiyogo, W. D. 2012. Penulisan Karya Tulis Ilmiah: Jurnal. Malang.

Hidayat, T. 2006. Metodologi Penulisan Artikel Ilmiah. Bandung. Retrieved from http://file.upi.edu/Direktori/FPMIPA/JUR. _PEND._BIOLOGI/197004101997021TO PIK_HIDAYAT/Penulisan_artikel_ilmiah. pdf

Hong, C. E., \& Lawrence, S. A. 2011. Action Research in Teacher Education: Classroom Inquiry, Reflection, and Data-Driven Decision Making. Journal of Inquiry \& Action in Education, 4(2), 1-17. Retrieved from http://digitalcommons.buffalostate.edu/cgi/ viewcontent .cgi article $=1038 \&$ context $=$ jia e
Kemdikbud. 2009. Peraturan Menteri Negara Pendayagunaan Aparatur Negara dan Reformasi Birokrasi Nomor 16 Tahun 2009 Tentang Jabatan Fungsional Guru dan Angka Kreditnya. Jakarta: Kementerian Pendidikan dan Kebudayaan.

Kemdikbud. 2016. Pedoman Kegiatan Pengembangan Keprofesian Berkelanjutan Bagi Guru Pembelajar. Jakarta: Kementerian Pendidikan dan Kebudayaan.

Kemis, S., \& Mc. Taggart, R. 1992. The Action Research Planner. Victoria: Deaken University.

Kunandar. 2008. Langkah Mudah Penelitian Tindakan Kelas Sebagai Pengembangan Profesi Guru. Jakarta: PT. Raja Grafindo.

Kunlasomboon, N., Wongwanich, S., \& Suwanmonkha, S. 2015. Research and Development of Classroom Action Research Process to Enhance School Learning. Procedia - Social and Behavioral Sciences, $\quad 171, \quad 1315-1324$. https://doi.org/10.1016/j.sbspro.2015.01.24 8

Kushartanti, W. 2014. Gaya selingkung jurnal. JPS-Lemlit-UNY, 1-4. Retrieved from http://staffnew.uny.ac.id/upload/13140589 8/pengabdian/GAYA+SELINGKUNG+JU RNAL.pdf

Mills, G. E. 2000. Action Research: A Guide for Teacher Researcher. London: Printice-Hall International (UK) Limited.

Sukardiyono, T. 2015. Pengertian, Tujuan, Manfaat, Karakteristik, Prinsip, dan Langkah-Langkah Penelitian Tindakan Kelas. Retrieved from http://staff.uny.ac.id/sites/default/files/peng abdian/drs-totok-sukardiyono-mt/makalahppm-ptk-2015.pdf

Wardhani, I. 2007. Teknik Menulis Karya Ilmiah. (E. R. Palupi, Ed.) (Edisi ke-3). Jakarta: Universitas Terbuka.

Widana, I. W. 2017a. Higher Order Thinking Skills Assessment ( HOTS ). Journal of 